\title{
Depth-acclimation of photosynthesis, morphology and demography of Posidonia oceanica and Cymodocea nodosa in the Spanish Mediterranean Sea
}

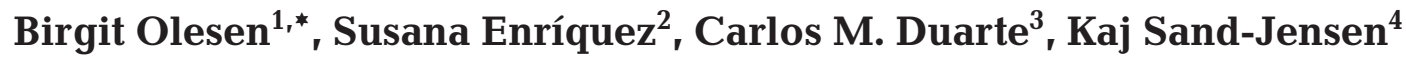 \\ ${ }^{1}$ Department of Plant Ecology, University of Aarhus, Nordlandsvej 68, 8240 Riskov, Denmark \\ ${ }^{2}$ Unidad Académia de Puerto Morelos, Instituto de Ciencias del Mar y Limnología, Universidad Nacional Autónoma de México, \\ Apto. Postal 1152, 77500 Cancún, Quintana Roo, Mexico \\ ${ }^{3}$ Instituto Mediterráno de Estudios Avanzados (SCIC-UIB), Miquel Marqués 21, 07190 Esporles, Islas Baleares, Spain \\ ${ }^{4}$ Freshwater Biological Laboratory, University of Copenhagen, 51 Helsingørsgade, 3400 Hillerød, Denmark
}

\begin{abstract}
Depth-related changes in population structure, biomass partitioning and photosynthesis were studied in populations of Cymodocea nodosa and Posidonia oceanica on the NE Spanish coast. The population structure of both species changed much more with depth than leaf morphology and physiology. Leaf biomass declined 5- to 7 -fold along the depth gradient reducing self-shading within the canopy, whereas the leaf area per unit leaf biomass and the photosynthesis-light response varied less than 1.5-fold among depths. Moreover, C. nodosa developed a greater proportion of leaves relative to rhizomes and roots at greater depths, thereby promoting the balance between photosynthesis and respiration in the shoots. C. nodosa, being a potentially fast-growing species compared to $P$. oceanica, had higher maximum photosynthetic and respiration rates as well as light compensation points for photosynthesis. Photosynthetic efficiency at low light, however, was almost the same for the 2 species as suggested by the relatively small differences in mass-specific light absorption. Only $C$. nodosa acclimated physiologically to depth as light-use efficiency increased, and light compensation point declined significantly from shallow to deep water. P. oceanica, however, possessed low respiration rates and slightly lower light compensation points values than $C$. nodosa throughout the depth range. Shoot mortality and recruitment rates were unaffected by rooting depth. C. nodosa stand experienced fast shoot turnover compared to $P$. oceanica, and shoot longevity of the former species decreased significantly with depth, suggesting higher risk of patch mortality at the depth limit. In contrast, . oceanica shoot longevity was highest at great depths. Overall, these species differences in leaf metabolism and shoot dynamics suggest that $C$. nodosa responds faster to changing light conditions, whereas $P$. oceanica is able to survive longer at low irradiance due to low growth and respiratory maintenance rates.
\end{abstract}

KEY WORDS: Seagrasses • Biomass partitioning ' Shoot demography · Leaf production · Photosynthetic light response Resale or republication not permitted without written consent of the publisher

\section{INTRODUCTION}

Light is often considered the principal factor regulating seagrass abundance and productivity through

*E-mail: birgit.olesen@biology.au.dk constraints on seasonal biomass development (SandJensen 1975, Marbà et al. 1996) and depth distribution (Dennison 1987, Duarte 1991a). Seagrasses receive approximately $11 \%$ of surface irradiance at their maximum colonisation depth (Duarte 1991a) and thus, are able to live in a variable and low light environment. 
At low light seagrass performance is enhanced through a range of acclimative responses (Backman \& Barilotti 1976, Dennison \& Alberte 1986, West 1990, Olesen \& Sand-Jensen 1993, Abal et al. 1994, Philippart 1995) leading to altered resource allocation patterns that tend to maximise the efficiency of light harvesting and its conversion into chemical energy while reducing respiratory costs (Björkman 1981).

Shade acclimation of aquatic plants is often accompanied by increased light utilisation efficiency and reduced respiratory rates of leaf tissue resulting in lower minimum light requirement for photosynthesis (Spence \& Chrystal 1970, Goldborough \& Kemp 1988, Maberly 1993). This response pattern is typically achieved by the combined influence of higher pigment content and larger leaf area per unit leaf biomass, increasing light absorption per unit weight of photosynthetic tissue (Enríquez et al. 1994, Markager \& Sand-Jensen 1994). Low light may also lead to a proportionally larger allocation of resources to leaves than to rhizomes/roots (Barko et al. 1982, Sand-Jensen \& Madsen 1991). In combination with a larger biomass-specific leaf area this leads to increased total leaf area relative to total shoot weight (Björkman 1981). In addition to these morphological changes, reduced shoot density and standing biomass are frequently observed (Chambers \& Kalff 1985a, Duarte 1991a, Krause-Jensen et al. 2000), thereby reducing self-shading within the canopy with less light above the canopy (Via et al. 1998).

Hence, light acclimation in seagrasses is a hierarchical process, involving processes occurring in leaves, individual shoots and the population structure. Although seagrass depth acclimation has been assessed in some detail, little information is available on the relative importance of acclimation at each of these levels (viz. Dennison \& Alberte 1985, 1986, Abal et al. 1994, Lee \& Dunton 1997).

Here, we examine light acclimation in the 2 Mediterranean seagrass species Posidonia oceanica (L.) Delile and Cymodocea nodosa (Ucria) Aschers growing along natural depth gradients. The 2 species dominate the seagrass vegetation within the Western Mediterranean, covering extensive areas down to depths of 40 to $50 \mathrm{~m}$ (Duarte 1991a) with P. oceanica dominating at larger depths (den Hartog 1970). The 2 species differ in module size and growth dynamics, as $P$. oceanica is a larger, more long-lived and slower-growing species than C. nodosa (Duarte 1991b), suggesting lower morphological and physiological plasticity in response to shading. Depth-related changes in shoot dynamics, biomass partitioning and photosynthetic light response of leaves were analysed to elucidate their relative contribution to overall depth acclimation. Additionally, species-specific differences in the acclimation to increasing rooting depth are evaluated.

\section{MATERIALS AND METHODS}

The study was conducted in June 1992 at the NE coast of Spain. Cymodocea nodosa was collected in the shallow (mean depth $3.2 \mathrm{~m}$ ) and relatively turbid (light attenuation coefficient, $k$ : $0.57 \mathrm{~m}^{-1}$; Duarte 1991a) Alfacs Bay (Tarragona) where C. nodosa grow from 0.4 to $3.8 \mathrm{~m}$ depth. Posidonia oceanica was collected at Port Lligat (Girona) in a protected bay characterised by low water turbidity $\left(k<0.2 \mathrm{~m}^{-1}\right.$; Marbà et al. 1996). At this study site a monospecific $P$. oceanica meadow extends from 0.7 to $15.6 \mathrm{~m}$ depth. Given the differences in water light attenuation and seagrass depth distribution at the 2 locations, $C$. nodosa and P. oceanica receive similar amounts of light (11.5 and $4.4 \%$ of surface irradiance, respectively) at the maximum sampling depth.

Posidonia oceanica and Cymodocea nodosa shoots were harvested along depth transects from 8 and 5 different rooting depths, respectively, with the maximum sampling depth close to the depth limit of the 2 seagrass species. P. oceanica shoot density was counted within triplicate $0.09 \mathrm{~m}^{2}$ quadrats, and 50 to 100 vertical short shoots with associated horizontal rhizomes were harvested at each sampling depth. For C. nodosa, all above and belowground biomass was harvested within three to nine $0.04 \mathrm{~m}^{2}$ quadrats at each sampling depth. The number of samples was augmented as shoot density declined at depth.

The biomass samples were transported to the laboratory, where we counted the number of harvested shoots, the number of standing leaves and leaf scars on all vertical shoots, and measured the distance between consecutive shoots on horizontal rhizomes. Shoot leaf area was estimated from measurements of leaf width and length of all standing leaves. Finally, the seagrass biomass, partitioned into leaves, rhizomes and roots, was dried at $85^{\circ} \mathrm{C}$ for $24 \mathrm{~h}$ and weighed. Biomass per ground area for Posidonia oceanica was calculated as the product of average shoot weight and shoot density.

The age of all living and dead (without green leaves) shoots was determined as the number of leaf scars on the vertical rhizome (plus the number of standing leaves for living shoots) formed during the life span of the shoot. The average annual leaf formation rate or plastochrone interval (PI, d leaf ${ }^{-1}$ ) was derived from annual cycles in rhizome internode lengths on the 5 to 10 oldest short shoots harvested. This analysis allowed us to translate the shoot age into absolute time units (viz. Duarte et al. 1994).

Shoot mortality and recruitment through clonal growth were estimated from the frequency distribution of shoot age as described by Duarte et al. (1994). Shoot mortality rates $\left(M, \ln\right.$ units $\left.\mathrm{yr}^{-1}\right)$ were derived from the exponential decline in shoot number with time, assum- 
ing constant recruitment and mortality rates among years and was calculated as:

$$
M=\left[\ln \left(N_{t}\right)-\ln \left(N_{0}\right)\right] t^{-1}
$$

where $N_{0}$ is number of shoots with modal age and $N_{t}$ is the number of shoots being $t$ time units older than the modal age. Shoot recruitment rate $\left(R, \ln\right.$ units $\left.\mathrm{yr}^{-1}\right)$ was calculated from the total number of shoots $(\mathrm{N})$ and the number of shoots older than $1 \mathrm{yr}\left(N_{\text {age }>1 y r}\right)$ present in the sampled population as:

$$
R=\ln (N)-\ln \left(N_{\text {age }>1 \text { yr }}\right)
$$

Shoot turnover time was determined as the average age-at-death of dead shoots. Subsequently, we calculated annual leaf biomass production as the product of the number of leaves formed per shoot per year and the mean weight of fully grown leaves. Horizontal rhizome elongation rates were estimated from the distance between consecutive shoots of known ages.

Physiological acclimation of leaves to rooting depth was evaluated from measured photosynthesis-irradiance (P-I) curves. Leaf material was sampled as described above. In the laboratory, apical leaf segments from the 2nd-youngest leaves were kept in seawater at low light $\left(\sim 50 \mu \mathrm{mol}\right.$ photons $\left.\mathrm{m}^{-2} \mathrm{~s}^{-1}\right)$ for less than $2 \mathrm{~d}$ before being used in experiments. Photosynthetic rates were determined from changes in dissolved oxygen concentration using micro-Winkler titration (Oudot et al. 1988). Leaf segments (5 cm long) corresponding to 30 to $40 \mathrm{mg}$ DW were placed in $60 \mathrm{ml}$ glass cuvettes filled with filtered, air-equilibrated seawater. Three reference cuvettes (without leaves) were incubated in parallel with 3 to 5 replicate cuvettes with leaves of 1 of the 2 seagrass species. The leaves were held in a fixed position within the cuvettes, perpendicular to the incident light source (halogen bulbs, Osram, $50 \mathrm{~W}$ ) to obtain a well-defined light climate at the leaf surfaces. Neutral density filters were used to obtain 7 different photon flux densities ( 0 to $400 \mathrm{mmol}$ photons $\mathrm{m}^{-2} \mathrm{~s}^{-1}$ ). The cuvettes were mounted on a rotating wheel in a thermostated incubator (20 to $22^{\circ} \mathrm{C}$ ). Following a $30 \mathrm{~min}$ acclimation period at each irradiance level to allow steady-state metabolism and oxygen exchange rates between leaf lacunae and seawater to become established, the water was renewed and incubations were run for 1 to $4 \mathrm{~h}$. At the completion of each irradiance treatment, oxygen concentrations were measured on water samples from all cuvettes and the incubation water was renewed. Rates of photosynthesis and dark respiration were then calculated after subtracting final oxygen concentrations in reference cuvettes.

The maximum photosynthetic rates $\left(P_{\max }\right)$ were obtained from photosynthetic rates at saturating irradiance (400 $\mathrm{umol}$ photons $\mathrm{m}^{-2} \mathrm{~s}^{-1}$ ). The photosynthetic efficiency $(\alpha)$ was calculated from the initial slope of the P-I curve $\left(<20 \mu \mathrm{mol}\right.$ photons $\left.\mathrm{m}^{-2} \mathrm{~s}^{-1}\right)$ by linear least-squares re- gression analysis (e.g. Ledermann \& Tett 1981), dark respiration rate $(\mathrm{R})$ was estimated from the intercept of the regression line on the ordinate and the light compensation point $\left(I_{\mathrm{C}}\right)$ from the intercept on the abscissa.

On the same leaf segments used for photosynthetic measurements, we determined biomass-specific leaf area (SLA; $\left.\mathrm{cm}^{2} \mathrm{~g}^{-1} \mathrm{DW}\right)$, chlorophyll $a+b(\mathrm{chl} a+b)$, nutrient (nitrogen, $\mathrm{N}$ and phosphorus, $\mathrm{P}$ ) content and light absorptance. Specific leaf area was obtained by measuring the DW (after drying at $85^{\circ} \mathrm{C}$ for $24 \mathrm{~h}$ ) of leaf segments of known area. $\mathrm{N}$ content of the dried leaf material was measured using a Carlo-Erba analyser and the $\mathrm{P}$ content was measured colorimetrically following wet acid digestion of the plant tissue (Koroleff 1983).

Light absorption was measured at $1 \mathrm{~nm}$ intervals across the PAR range (400 to $700 \mathrm{~nm}$ ) in a dualbeam scanning spectrophotometer (Shimadzu UV-2100) equipped with an opal glass unit (cf. Enríquez et al. 1994). We used the technique developed for intact leaves by Shibata (1959). The absorbance values obtained were corrected by subtracting absorption at $750 \mathrm{~nm}$ to exclude residual scattering (Duysens 1956). The absorbance value at the chl a peak at $680 \mathrm{~nm}$ is a good descriptor of average PAR absorption (Enríquez et al. 1994) and was used because subtraction of the absorbance value at $750 \mathrm{~nm}$ also excludes tissue absorption (Duysens 1956). Leaf light absorption was expressed as absorptance (the fraction of light absorbed) at the $680 \mathrm{~nm}$ chl a peak, calculated from the absorbance measurements (optical density, OD) using the equation: Absorptance $=1-10^{- \text {absorbance }}$ (Kirk 1994), and as light absorbed per unit of leaf biomass (weight-specific absorption).

Chl $a+b$ content was determined on leaf segments used for absorption measurements following grounding and pigment extraction in $80 \%$ acetone (Dennison 1990). Pigment concentrations were expressed per unit DW using the measured leaf area/DW ratio.

The importance of rooting depth for the observed variability in seagrass performance among sampling depths was evaluated by correlation analysis between the measured parameters and log-transformed depths. Samples from the shallowest stands of Cymodocea nodosa $(0.4 \mathrm{~m})$ and Posidonia oceanica $(0.7 \mathrm{~m})$ were, however, omitted from the correlation analysis as the measured variables were likely to be limited by factors other than light, such as exposure to air and wave damage.

\section{RESULTS}

\section{Biomass and shoot density}

Posidonia oceanica and Cymodocea nodosa differed widely in total biomass and shoot density. P. oceanica 
shoots were large and developed meadows with high aboveground biomass, but had low shoot density compared to C. nodosa (Fig. 1). Belowground biomass (rhizomes and roots) of the 2 seagrass species were, however, of similar magnitude (not shown). Aboveground biomass of both seagrass species was significantly related to sampling depth ( $P$. oceanica: $\mathrm{r}=-0.873$, $\mathrm{p}<0.01$ and $C$. nodosa: $\mathrm{r}=-0.945, \mathrm{p}<0.05$, Table 1 ) and showed a 5 - to 7 -fold decline from shallow to deep water (Fig. 1). Leaf area index varied from 2.6 to $12.9 \mathrm{~m}^{2} \mathrm{~m}^{-2}$ between sampling depths for $P$. oceanica and from 0.7 to $3.4 \mathrm{~m}^{2} \mathrm{~m}^{-2}$ for $C$. nodosa and was closely related to changes in the aboveground biomass of both species $(r=0.985, p<0.001$ and $r=0.949$, $p<$ 0.05 , respectively; data not shown). The decline in leaf biomass with depth was directly related to shoot density ( $P$. oceanica: $\mathrm{r}=0.938, \mathrm{p}<0.001 ; C$. nodosa: $\mathrm{r}=$ $0.980, \mathrm{p}<0.01)$. Accordingly, variability in average shoot weight among depths was low and independent of sampling depth (Table 1). The ratio of above- to belowground biomass was unaffected by rooting depth in both species (Fig. 1, Table 1). At shallow and intermediate water depths, the biomass ratio of $P$. oceanica was higher than for C. nodosa while the ratio was of similar magnitude $(0.7)$ for the 2 species at greater depths.

\section{Plant growth}

Posidonia oceanica shoots formed new leaves at low rates and had lower rhizome elongation rates compared to Cymodocea nodosa shoots (Fig. 1). However, leaf biomass production per shoot was 3 to 12 -fold higher for $P$. oceanica than for C. nodosa due to the larger shoot weight of the former species.

The number of leaves formed per year was unrelated to sampling depth for both seagrass species (Table 1). As shoot size of Posidonia oceanica showed similar low variability, rates of
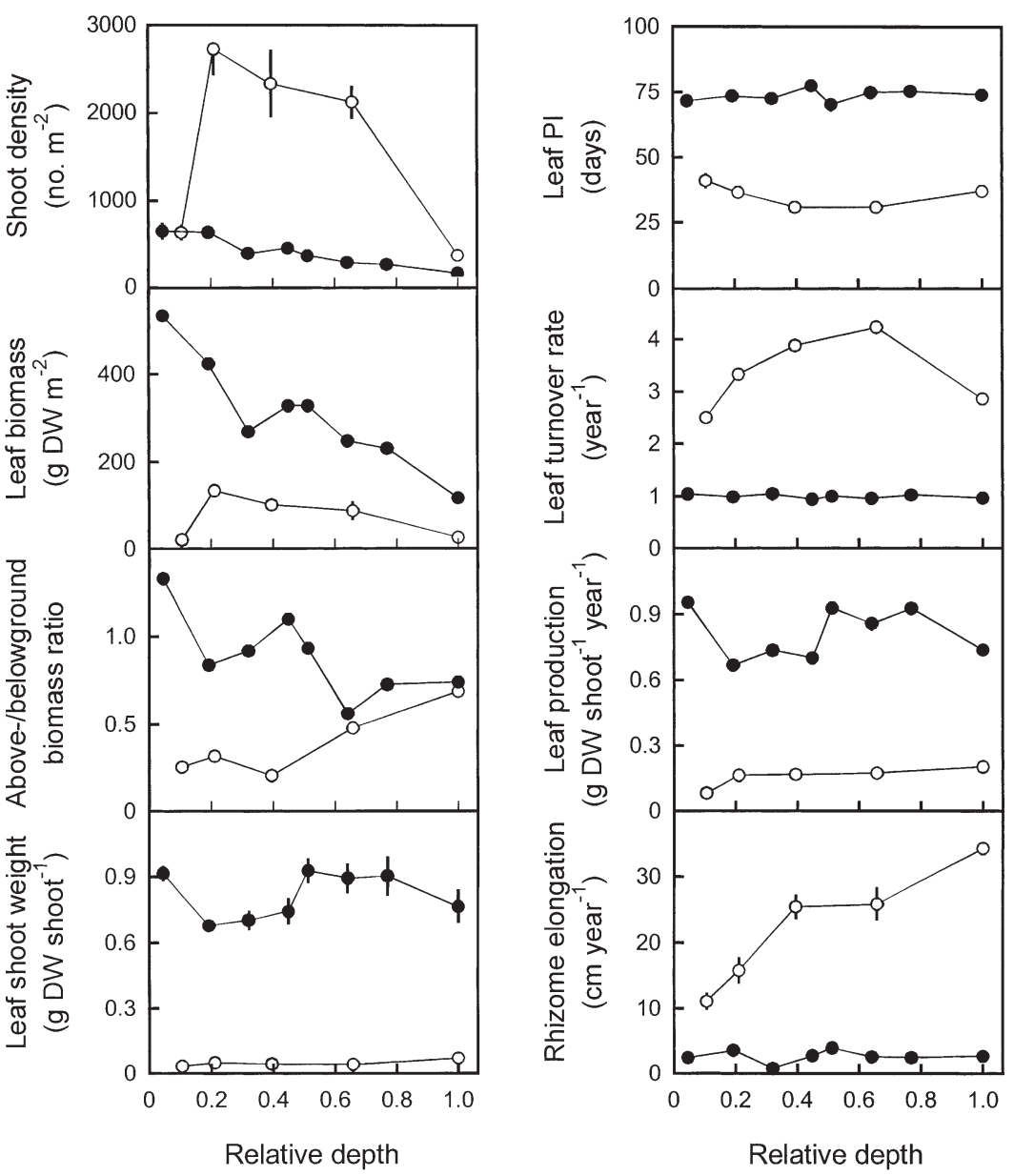

Fig. 1. Population structure and growth of Posidonia oceanica (•) and Cymodocea nodosa (O) along depth gradients from 0.7 to $15.6 \mathrm{~m}$ and 0.4 to $3.8 \mathrm{~m}$, respectively. Depths are shown relative to the maximum depth of colonisation. Data are mean $\pm \mathrm{SE}$ leaf biomass turnover were also uniform among depths (range: 0.94 to $1.05 \mathrm{yr}^{-1}$ ) for this species. Leaf turnover of Cymodocea nodosa was more variable (range: 2.5 to $4.2 \mathrm{yr}^{-1}$ ), with the highest rates attained at intermediate depths (Fig. 1). Leaf production per shoot was unaffected by rooting depth (Table 1) and hence, leaf production per ground area declined 5- to 6-fold with depth in both species (not shown) due to the marked decline in shoot density. Rhizome elongation rates were highly variable among depths (Fig. 1) and only C. nodosa showed a consistent depth-related increase $(\mathrm{r}=$ 0.956, p < 0.05).

\section{Shoot dynamics}

Posidonia oceanica populations displayed considerably lower shoot recruitment and mortality rates compared to Cymodocea nodosa populations (Fig. 2). Accordingly, P. oceanica shoots were long-lived and displayed longer turnover times (4 to $9 \mathrm{yr}$ ) than C. nodosa shoots (0.6 to $1.1 \mathrm{yr}$ ).

Mortality and recruitment rates of Posidonia oceanica displayed similar rates among depths except in shallow stands $(0.8 \mathrm{~m})$, where rates were approximately 2 -fold higher. However, 

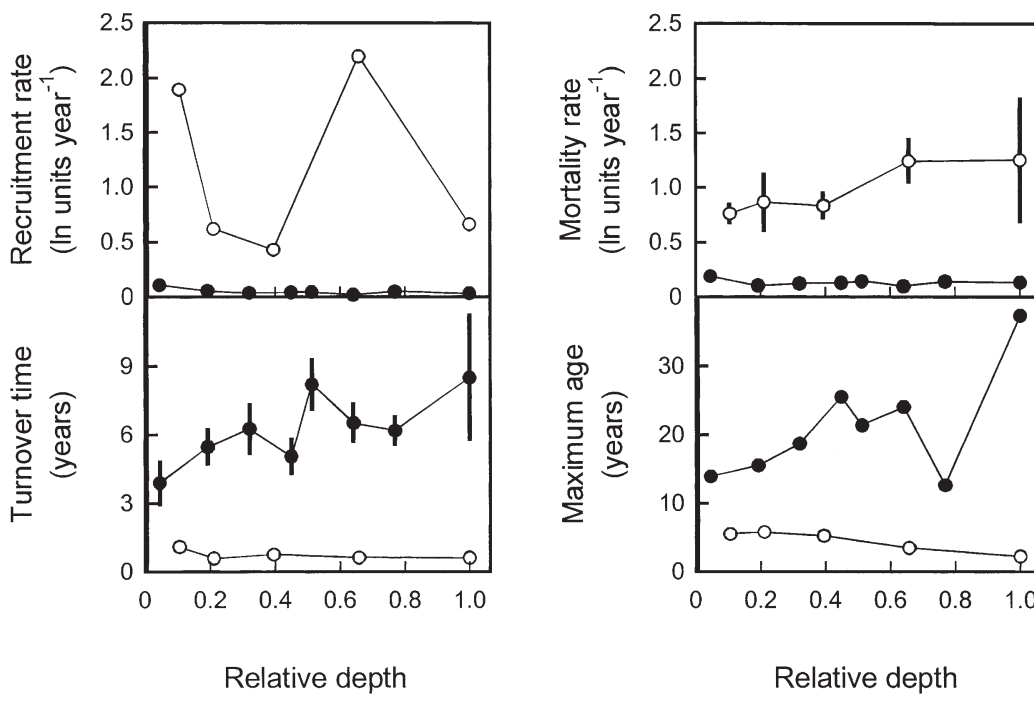

Fig. 2. Shoot dynamics and maximum age of Posidonia oceanica $(\bullet)$ and Cymodocea nodosa (O) along depth gradients from 0.7 to $15.6 \mathrm{~m}$ and 0.4 to $3.8 \mathrm{~m}$, respectively. Depths are shown relative to the maximum depth of colonisation.

Data are mean $\pm \mathrm{SE}$

higher maximum shoot age and longer turnover time at deep greater depths suggest a decline in mortality among old compared to young shoots with depth (Fig. 2). Mortality and recruitment rates of Cymodocea nodosa were uncoupled and the observed variability was unrelated to depth (Fig. 2, Table 1). The high recruitment rates encountered at intermediate depths probably reflect recent recolonisation of the populations by increased vegetative reproduction of surviving shoots. Accordingly, $50 \%$ of all shoots at this depth were younger than $0.3 \mathrm{yr}$ as compared to $1.9 \mathrm{yr}$ at the other sampling depths (not shown). In contrast, shoot turnover time only varied little among depths, reflecting similar shoot age at death for shoots produced at different time and depths when averaged over several years. Maximum shoot age, however, declined significantly with depth $(r=0.970$, $\mathrm{p}<0.05)$.

\section{Leaf morphology and photosynthesis}

Variability in leaf $\mathrm{N}$ content was low (Posidonia oceanica: 1.5 to $2.1 \%$ DW, Cymodocea nodosa: 2.9 to $3.4 \%$ DW) and unaffected by depth, whereas the content of $\mathrm{P}$

Table 1. Correlation coefficients (r) and significance levels for relationships between changes in population structure, plant growth, shoot demography, and leaf morphology and physiology of Posidonia oceanica and Cymodocea nodosa and rooting depth. Relationships were considered statistically significant if ${ }^{*} p<0.05,{ }^{* *} p<0.01$ and ${ }^{* * *} p<0.001$. ns: non-significant

\begin{tabular}{|c|c|c|c|c|}
\hline \multirow[t]{2}{*}{ Variable } & \multicolumn{2}{|c|}{ Posidonia oceanica } & \multicolumn{2}{|c|}{ Cymodocea nodosa } \\
\hline & $\mathrm{r}$ & Significance & $\mathrm{r}$ & Significance \\
\hline \multicolumn{5}{|l|}{ Population structure } \\
\hline Shoot density (shoots $\mathrm{m}^{-2}$ ) & -0.954 & $* * *$ & -0.865 & ns \\
\hline Leaf biomass ( $\mathrm{g} \mathrm{DW} \mathrm{m}^{-2}$ ) & -0.873 & $* *$ & -0.945 & $*$ \\
\hline Leaf/rhizome+root biomass ratio & -0.429 & ns & 0.809 & ns \\
\hline Leaf shoot weight (g DW shoot ${ }^{-1}$ ) & 0.621 & ns & 0.528 & ns \\
\hline \multicolumn{5}{|l|}{ Plant growth } \\
\hline Leaf plastochrone interval (d) & 0.198 & ns & -0.031 & ns \\
\hline Leaf turnover rate $\left(\mathrm{yr}^{-1}\right)$ & -0.219 & ns & -0.149 & ns \\
\hline Leaf production (g DW shoot ${ }^{-1} \mathrm{yr}^{-1}$ ) & 0.535 & ns & 0.862 & ns \\
\hline Rhizome elongation (cm apex ${ }^{-1} \mathrm{yr}^{-1}$ ) & -0.033 & ns & 0.956 & $*$ \\
\hline \multicolumn{5}{|l|}{ Shoot demography } \\
\hline Shoot recruitment (ln[units] $\mathrm{yr}^{-1}$ ) & -0.517 & ns & 0.336 & ns \\
\hline Shoot mortality (ln[units] $\mathrm{yr}^{-1}$ ) & 0.471 & ns & 0.870 & ns \\
\hline Shoot turnover (yr) & 0.589 & ns & -0.034 & ns \\
\hline Maximum shoot age (yr) & 0.534 & ns & -0.969 & * \\
\hline \multicolumn{5}{|l|}{ Leaf morphology and physiology } \\
\hline Biomass specific leaf area $\left(\mathrm{cm}^{2} \mathrm{~g}^{-1} \mathrm{DW}\right)$ & 0.772 & * & 0.996 & ** \\
\hline Chlorophyll $a+b\left(\mathrm{mg} \mathrm{g}^{-1} \mathrm{DW}\right)$ & 0.557 & ns & 0.876 & ns \\
\hline Light absorptance (\%) & 0.294 & ns & 0.628 & ns \\
\hline Weight-specific absorption $\left(\mathrm{cm}^{-2} \mathrm{mg}^{-1} \mathrm{DW}\right)$ & 0.647 & ns & 0.955 & * \\
\hline Maximum photosynthesis $\left(\mu \mathrm{mol} \mathrm{O}_{2} \mathrm{~g}^{-1} \mathrm{DW} \mathrm{h}^{-1}\right)$ & 0.177 & ns & 0.973 & * \\
\hline Photosynthetic efficiency $\left(\left[\mu \mathrm{mol} \mathrm{O} \mathrm{O}^{-1} \mathrm{DW} \mathrm{h} \mathrm{h}^{-1}\right]\left[\mu \mathrm{mol} \text { photons } \mathrm{m}^{-2} \mathrm{~s}^{-1}\right]^{-1}\right)$ & 0.077 & ns & 0.950 & * \\
\hline Respiration $\left(\mu \mathrm{mol} \mathrm{O} \mathrm{g}^{-1} \mathrm{DW} \mathrm{h}^{-1}\right)$ & -0.244 & ns & 0.610 & ns \\
\hline Light compensation point ( $\mu \mathrm{mol}$ photons $\mathrm{m}^{-2} \mathrm{~s}^{-1}$ ) & -0.294 & ns & 0.978 & * \\
\hline
\end{tabular}


was more variable (P. oceanica: 0.10 to $0.16 \%$ DW, C. nodosa: 0.16 to $0.27 \%$ DW) and increased significantly with depth for C. nodosa ( $\mathrm{r}=0.995, \mathrm{p}<0.01$; data not shown).

Concentrations of leaf chl $a+b$ in the 2 seagrass species were of similar magnitude whereas the mass specific leaf area was lower for Posidonia oceanica compared to $C y$ modocea nodosa (Fig. 3), resulting in a 1.1- to 2.9-fold higher pigment content per unit leaf area of the former species (not shown). Chl $a+b$ concentration was independent of depth whereas leaf area per unit biomass increased significantly with increasing depth in both seagrass species (P. oceanica: $\mathrm{r}=0.772, \mathrm{p}<0.05 ; C$. nodosa: $\mathrm{r}=0.996, \mathrm{p}<0.01$; Fig. 3, Table 1).

The fraction of light absorbed by leaves at the chl $a$ peak (absorptance at $680 \mathrm{~nm}$ ) was high (>90\%) in both species and constant among depth (Fig. 3, Table 1). Hence, the weight-specific absorption of leaves was of similar magnitude for the 2 species and only increased significantly $(\mathrm{r}=0.955, \mathrm{p}<0.5)$ with depth for Cymodocea nodosa (Fig. 3, Table 1).

Photosynthetic rates measured at light saturation and respiration rates of Cymodocea nodosa leaves were high compared to Posidonia oceanica, whereas both species showed similar light utilisation efficiencies (Fig. 3). The light compensation points for $P$. oceanica leaves varied between 3.1 and $5.4 \mathrm{mmol}$ photons $\mathrm{m}^{-2} \mathrm{~s}^{-1}$ and were somewhat lower than those of C. nodosa (range: 5.7 to $10.7 \mu \mathrm{mol} \mathrm{m} \mathrm{m}^{-2} \mathrm{~s}^{-1}$ ). Of the 2 seagrass species, only C. nodosa showed significant depth-related changes in photosynthetic parameters (Table 1). Hence, photosynthetic efficiency increased 1.5-fold with depth leading to a low light compensation point near the depth limit, albeit respiration rates remained constant (Fig. 3).

\section{DISCUSSION}

\section{Role of physiology, morphology and demography in depth acclimation}

Depth acclimation of Posidonia oceanica and Cymodocea nodosa were considerably more pronounced for the population structure than at the level of individual shoots or leaves. Hence, shoot density and leaf biomass declined 5- to 7 -fold along the depth gradient whereas shoot morphology and leaf photosynthesis varied less than 1.5-fold, and only C. nodosa displayed reduced photosynthetic light requirements with depth.

In natural seagrass meadows, depth acclimation is influenced by light attenuation through the water column and through the canopy. Reductions in seagrass shoot density along depth gradients can substantially enhance the relative amount of light available for absorption per shoot within the canopy, particularly in large species (Via et al. 1998, Krause-Jensen et al. 2000). Accordingly, reduced self-shading with depth may, at least partly, account for the moderate depth-related changes in leaf metabolism and growth observed here and in other studies of seagrass depth acclimation (Bulthuis 1983, Dennison \& Alberte 1985, Pirc 1986, Buia et al. 1992, Iizumi 1996, Alcoverro et al. 2001a).

Another typical response to shading involves changed shoot and leaf morphology such as increased
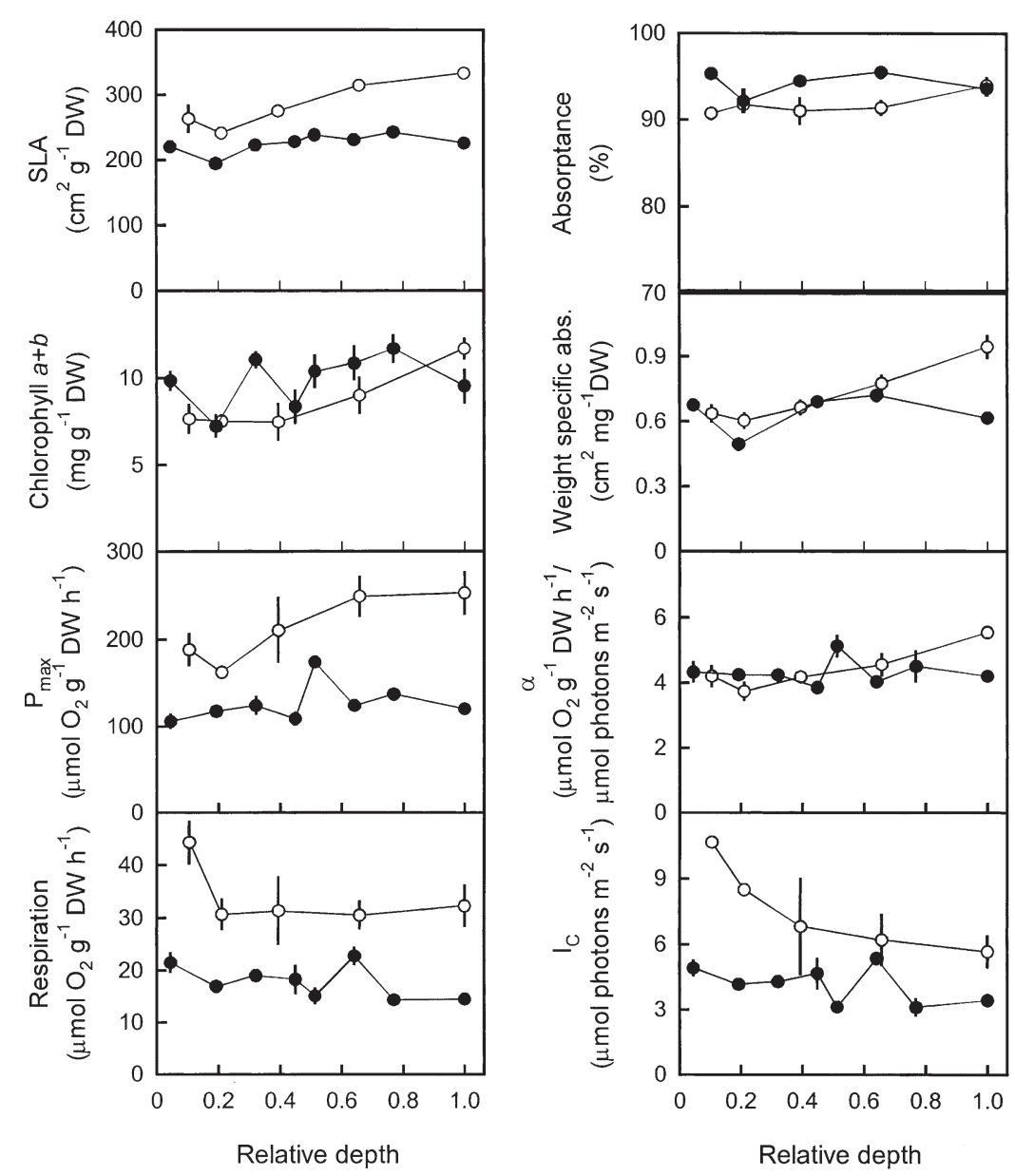

Fig. 3. Leaf morphology, pigment content, light absorption and photosynthetic light response of Posidonia oceanica (•) and Cymodocea nodosa (0) along depth gradients from 0.7 to $15.6 \mathrm{~m}$ and 0.4 to $3.8 \mathrm{~m}$, respectively. Depths are shown relative to the maximum depth of colonisation. SLA: specific leaf area, $P_{\max }:$ maximum photosynthetic rate, $\alpha$ : light use efficiency, $I_{\mathrm{C}}$ : light compensation points. Data are mean $\pm \mathrm{SE}$ 
above/belowground biomass ratio and mass-specific leaf area as observed here for Cymodocea nodosa and other aquatic vascular plants (Chambers \& Kalff 1985b, Sand-Jensen \& Søndergaard 1997). Likewise, macrophytes may produce longer leaves or stems extending towards the water surface (Goldsborough \& Kemp 1988, Maberly 1993, Krause-Jensen et al. 2000). Such changes in biomass partitioning can be as important to shade acclimation as changes in photosynthetic light response (Goldsborough \& Kemp 1988, Maberly 1993, Sand-Jensen \& Søndergaard 1997). Metabolic plasticity frequently described in laboratory shading experiments (Spence \& Chrystal 1970, Bowes et al. 1977) may, therefore, overemphasise the importance of photosynthetic acclimation to natural light gradients, ignoring acclimation processes at other levels of plant organisation, which may induce substantial changes in the light environment of leaves and reduce wholeplant respiratory costs.

\section{Morphological and physiological flexibility}

Although changes in photosynthetic parameters with depth were small, differences were distinct between the 2 seagrass species. Only Cymodocea nodosa, being a potentially faster growing species compared to Posidonia oceanica, reduced photosynthetic light requirements of leaves with depth. This agrees with the general view that the morphological and physiological flexibility of inherent slow-growing plant species is low (Lambers \& Porter 1992). Nevertheless, leaf area per unit leaf biomass, which is considered a key factor in explaining differences in physiological shade acclimation among plant species (Björkman 1981, Enríquez et al. 1994, Markager \& Sand-Jensen 1994), was only slightly higher for $C$. nodosa compared to $P$. oceanica. Moreover, light absorptance was always high ( $>90 \%$ ) leading to similar light absorption per unit leaf biomass and accordingly, photosynthetic light use efficiency was almost the same for the 2 species. More prominent changes in photosynthetic rates with depth have, however, been found in fast-growing freshwater macrophytes (Spence et al. 1973, Goldsborough \& Kemp 1988, Maberly 1993), which may be more metabolically plastic due to thinner leaves and more flexible leaf morphology.

Although Cymodocea nodosa leaves reduced their light requirement for photosynthesis with depth, the light compensation point was higher than for Posidonia oceanica near the depth limit ( $t$-test, $p=0.0142)$, due to higher respiration rates of the former species. Photosynthetic characteristics determined with leaf segments in a unidirectional light field cannot, however, be used to predict differences among species in light requirements for growth in natural populations. Photosynthetic rates depend on leaf age (Alcoverro et al. 1999) and the carbon budget of whole plants is affected by the belowground biomass, which can significantly increase the minimum light requirement to sustain growth (Fourqurean \& Zieman 1991, Dunton \& Tomasko 1994).

\section{Shoot dynamics and depth acclimation}

Neither of the 2 seagrass species showed significant depth-related changes in shoot recruitment and mortality rates. The fast turnover time ( $0.6 \mathrm{yr}$ ) of Cymodocea nodosa shoots compared to Posidonia oceanica $(8.5 \mathrm{yr})$ is, however, indicative of a much faster response to fluctuating conditions at the depth limit, where the risk of encountering severe shading or anoxic sediments with high content of reductants is higher. Accordingly, C. nodosa shoots reached a lower maximum age near the depth limit than in shallow stands whereas the oldest $P$. oceanica shoots were recorded in deep growing stands. Higher shading tolerance of large seagrass species is a likely consequence of their slow growth rates. The slow leaf turnover rates of $P$. oceanica $\left(\sim 1 \mathrm{yr}^{-1}\right)$ restricts losses of acquired resources invested in shoot tissue whereas the comparatively faster leaf turnover of C. nodosa $\left(\sim 2.5 \mathrm{yr}^{-1}\right)$ suggests substantial carbon losses and thereby a relatively larger resource partitioning to leaves in order to sustain growth. In addition, carbohydrate reserves are critical for seagrass survival, supporting growth and respiratory requirements when leaf photosynthesis is inadequate to maintain a positive carbon balance (Kraemer \& Alberte 1995, Lee \& Dunton 1997, Alcoverro et al. 1999, 2001b). Large seagrass species tend to have larger and more persistent rhizomes (Duarte 1991b), suggesting potential high carbon storage but also high carbon demand for maintenance. The share of belowground biomass in total plant respiration depends on the biomass of leaves. However, given the low biomass-specific respiration rates of large seagrass species as indicated by Alcoverro et al. (2001b) and thereby low carbon depletion rates, storage capacity for carbohydrates is expected to be higher for large slow-growing seagrass species.

In summary, depth-related reduction in shoot density of Cymodocea nodosa and Posidonia oceanica was the most effective acclimation process found in this study. Morphology and photosynthetic light requirements of leaves displayed low variability, and only the smaller and faster growing $C$. nodosa adjusted physiologically to rooting depth by reducing the minimum light requirement for photosynthesis. $P$. oceanica was 
less plastic and already possessed low respiration rates and thus, low minimum light requirements for photosynthesis. Once established within an area, growth and survival of seagrasses depends critically on the scale of environmental variation and the time interval between module formations. In accordance with the inherently slow growth rates of modules and high shoot longevity, P. oceanica is expected to respond more slowly to environmental perturbations compared to $C$. nodosa, where abnormal low light in 1 season may cause substantial shoot mortality. However, high rates of module formation and rhizome elongation of C. nodosa enables the plant to colonise much faster during suitable periods, allowing the species to survive under fluctuating environmental conditions.

Acknowledgements. We thank J. Cebrián, M. E. Gallegos and N. Marbà for their assistance in the field and the laboratory.

\section{LITERATURE CITED}

Abal EG, Loneragan N, Bowen P, Perry CJ, Udy JW, Dennison WC (1994) Physiological and morphological responses of the seagrass Zostera carpricorni Aschers. to light intensity. J Exp Mar Biol Ecol 178:113-119

Alcoverro T, Zimmerman RC, Kohrs DG, Alberte RS (1999) Resource allocation and sucrose mobilization in lightlimited eelgrass Zostera marina. Mar Ecol Prog Ser 187: 121-131

Alcoverro T, Cerbian E, Ballesteros E (2001a) The photosynthetic capacity of the seagrass Posidonia oceanica: influence of nitrogen and light. J Exp Mar Biol Ecol 261:107-120

Alcoverro T, Manzanera M, Romero J (2001b) Annual metabolic carbon balance of the seagrass Posidonia oceanica: the importance of carbohydrate reserves. Mar Ecol Prog Ser 211:105-116

Backman TW, Barilotti DC (1976) Irradiance reduction: effects on standing crops of the eelgrass Zostera marina in a coastal lagoon. Mar Biol 34:33-40

Barko JW, Hardin DG, Matthews MS (1982) Growth and morphology of submersed freshwater macrophytes in relation to light and temperature. Can J Bot 60:877-887

Björkman O (1981) Responses to different quantum flux densities. In: Lange OL, Nobel PS, Osmond CB, Ziegler $\mathrm{H}$ (eds) Encyclopaedia of plant physiology, Vol 12A. Springer-Verlag, Berlin, p 57-107

Bowes G, Van TK, Garrard LA, Haller WT (1977) Adaptation to low light levels by Hydrilla. J Aquat Plant Manag 15: 32-35

Buia MC, Zupo V, Mazzella L (1992) Primary production and growth dynamics in Posidonia oceanica. PSZN I: Mar Ecol 13:2-16

Bulthuis DA (1983) Effects of in situ light reduction on density and growth of the seagrass Heterozostera tasmanica (Martens ex Aschers.) den Hartog in Western Port, Victoria, Australia. J Exp Biol Ecol 67:91-103

Chambers PA, Kalff J (1985a) Depth distribution and biomass of submersed aquatic macrophyte communities in relation to Secchi depth. Can J Fish Aquat Sci 42:701-709

Chambers PA, Kalff J (1985b) The influence of sediment composition and irradiance on the growth and morphology of Myriophyllum spicatum L. Aquat Bot 22:253-263 den Hartog C (1970) The sea-grasses of the world. NorthHolland Publishing, Amsterdam

Dennison WC (1987) Effects of light on seagrass photosynthesis, growth and depth distribution. Aquat Bot 27:15-26

Dennison WC (1990) Chlorophyll content. In: Phillips RC, McRoy CP (eds) Seagrass research methods. UNESCO, Paris, p 83-85

Dennison WC, Alberte RS (1985) Role of daily light period in the depth distribution of Zostera marina (eelgrass). Mar Ecol Prog Ser 25:51-61

Dennison WC, Alberte RS (1986) Photoadaptation and growth of Zostera marina L. (eelgrass) transplants along a depth gradient. J Exp Mar Biol Ecol 98:265-282

Duarte CM (1991a) Seagrass depth limits. Aquat Bot 40: 363-377

Duarte CM (1991b) Allometric scaling of seagrass form and productivity. Mar Ecol Prog Ser 77:289-300

Duarte CM, Marbà N, Agawin N, Cebrián J and 8 others (1994) Reconstruction of seagrass dynamics: age determinations and associated tools for the seagrass ecologist. Mar Ecol Prog Ser 107:195-209

Dunton KH, Tomasko DA (1994) In situ photosynthesis in the seagrass Halodule wrightii in a hypersaline subtropical lagoon. Mar Ecol Prog Ser 107:281-293

Duysens LMN (1956) The flattening effect of the absorption spectra of suspensions as compared to that of solutions. Biochem Biophys Acta 19:1-12

Enríquez S, Agustí S, Duarte CM (1994) Light absorption by marine macrophytes. Oecologia 98:121-129

Fourqurean JW, Zieman JC (1991) Photosynthesis, respiration and whole plant carbon budget of the seagrass Thalassia testudinum. Mar Ecol Prog Ser 69:161-170

Goldsborough WJ, Kemp WM (1988) Light responses of a submersed macrophyte: implications for survival in turbid tidal waters. Ecology 69:1775-1786

Iizumi $H$ (1996) Temporal and spatial variability of leaf production of Zostera marina L. at Otsuchi, Northern Japan. In: Kuo J, Phillips RC, Walker DI, Kirkman H (eds) Seagrass biology: Proc Int Workshop, Rottnest Island, Western Australia, 25-29 January 1996. Faculty of Science, University of Western Australia, p 143-148

Kirk JTO (1994) Light and photosynthesis in aquatic ecosystems, 2nd edn. Cambridge University Press, Cambridge

Koroleff F (1983) Determination of phosphorus. In: Grasshoff K, Egrardt M, Kremling K (eds) Methods of seawater analysis, 2nd edn. Verlag Chemie, Nürnberg, p 125-139

Kraemer GP, Alberte RS (1995) Impact of daily photosynthetic period on protein synthesis and carbohydrate stores in Zostera marina L. (eelgrass) roots: implications for survival in light-limited environments. J Exp Mar Biol Ecol 185: 191-202

Krause-Jensen D, Middelboe AL, Sand-Jensen K, Christensen PB (2000) Eelgrass, Zostera marina, growth along depth gradients: upper boundaries of the variation as a powerful predictive tool. Oikos 91:233-244

Lambers H, Poorter H (1992) Inherent variation in growth rate between higher plants: a search for physiological causes and ecological consequences. Adv Ecol Res 23: $188-261$

Ledermann TC, Tett P (1981) Problems in modeling the photosynthesis-light relationship for phytoplankton. Bot Mar 24:125-134

Lee KS, Dunton KH (1997) Effects of in situ light reduction on the maintenance, growth and partitioning of carbon resources in Thalassia testudinum. J Exp Mar Biol Ecol 210:53-73

Maberly SC (1993) Morphological and photosynthetic charac- 
teristics of Potamogeton obtusifolius from different depths. J Aquat Plant Manag 31:34-39

Marbà N, Cebrián J, Enríquez S, Duarte CM (1996) Growth patterns of Western Mediterranean seagrasses: speciesspecific responses to seasonal forcing. Mar Ecol Prog Ser 133:203-215

Markager S, Sand-Jensen K (1994) The physiology and ecology of light-growth relationship in macroalgae. Prog Physiol Res 10:209-211

Olesen B, Sand-Jensen K (1993) Seasonal acclimatization of eelgrass Zostera marina growth to light. Mar Ecol Prog Ser 94:91-99

Oudot C, Gerard R, Morin P, Gningue I (1988) Precise shipboard determination of total dissolved oxygen (Winkler procedure) for productivity studies with a commercial system. Limnol Oceanogr 33:146-150

Philippart CJM (1995) Effects of shading on growth, biomass and population maintenance of the intertidal seagrass Zostera noltii Hornem. in the Dutch Wadden Sea. J Exp Mar Biol Ecol 188:199-213

Pirc H (1986) Seasonal aspects of photosynthesis in Posidonia oceanica: influence of depth, temperature and light intensity. Aquat Bot 26:203-212

Sand-Jensen K (1975) Biomass, net production and growth dynamics in an eelgrass (Zostera marina L.) population in Vellerup Vig, Denmark. Ophelia 14:185-201

Editorial responsibility: Otto Kinne (Editor),

Oldendorf/Luhe, Germany
Sand-Jensen K, Madsen TV (1991) Minimum light requirements of submerged freshwater macrophytes in laboratory growth experiments. J Ecol 79:749-764

Sand-Jensen K, Søndergaard M (1997) Plants and environmental conditions in Danish Lobelia-lakes. In: SandJensen K, Pedersen O (eds) Freshwater biology. Priorities and development in Danish research. The Freshwater Biological Laboratory, University of Copenhagen and GEC Gad Publishers, Copenhagen, p 54-73

Shibata K (1959) Spectrophotometry of translucence biological materials - opal glass transmission method. Methods Biochem Anal 7:77-109

Spence DHN, Chrystal J (1970) Photosynthesis and zonation of freshwater macrophytes. II. Adaptability of species of deep and shallow water. New Phytol 69:217-227

Spence DHN, Campbell RM, Chrystal J (1973) Specific leaf areas and zonation of freshwater macrophytes. J Ecol 61:317-328

Via JD, Sturmbauer C, Schönweger G, Sötz E, Mathekowitsch S, Stifter M, Rieger R (1998) Light gradients and meadow structure in Posidonia oceanica: ecomorphological and functional correlates. Mar Ecol Prog Ser 163: $267-278$

West RJ (1990) Depth-related structural and morphological variations in an Australian Posidonia seagrass bed. Aquat Bot 36:153-166

Submitted: November 1, 1999; Accepted: February 12, 2002 Proofs received from author(s): May 21, 2002 